\title{
IS ER STRIJD TUSSCHEN DE GELIJKMATIGHEID DER VERSCHIJNSELEN OP MAATSCHAPPELIJK GEBIED, EN DEN VRIJEN WIL VAN HET INDIVIDU?
}

Ik val dadelijk met de deur in huis en kom met mijne cijfers voor den dag, beloof echter daarmede spaarzaam te zullen ziju.

Uit eene hierachter gevoegde tabel A ziet men dat van de 1000 huwelyken die voltrokken werden gedurende de jaren 1850-54 over het geheele rijk, zijn aangegaan gemıddeld per jaar:

788 tusschen jongmans en jonge dochters.

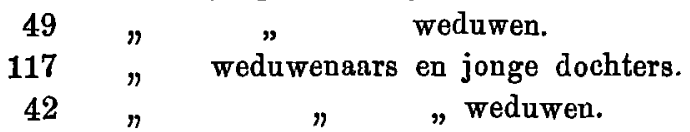

en gedurende de vijf daarop volgende jaren :

783 tusschen jongmans en jonge dochters.

" weduwen.

$121 \quad \Rightarrow \quad$ weduwenaars en jonge dochters.

43

" "weduwen.

Het zal mij niet worden betwist, wanneer ik zeg, dat dat constante cyfers zijn, die genomen over eene bevolking, als ons land telt, mogen gezegd worden, in die twee tijdperken..... geen noemenswaardig verschil op te leveren.

Zien wij, hoe het te dien aanzien op een beperkter gebıed, de stad Groningen, gesteld is. (tabel B.)

In die stad dan werden gemiddeld gesloten, gedurende de jaren 1852/57, jaarlijks :

217 huwelijken tusschen jongmans en jonge dochters.

11
37
$\frac{15}{280} "$

$n$

$$
\begin{gathered}
\text { weduwenaars en jonge dochters. } \\
" n \quad \text { "weduwen. }
\end{gathered}
$$

Ficon, 1869 . 
en gedurende de vijf daaropvolgende jaren :

238 huwelyken tusschen jongmans en jonge dochters.

\begin{tabular}{cccc}
13 & & & \multicolumn{2}{c}{ weduwen } \\
48 & $n$ & $"$ & weduwenaars en jonge dochters. \\
20 & $"$ & $"$ & $\#, \quad$ weduwen.
\end{tabular}

Oogenschijnljik bestaat hier meer verschil

Ik zeg oogenschijnlijk, immers dat vervalt bij nader aanschouwen;

$1^{0}$ toch bewegen wij ons hier op een klenner gebled, waar de gelijkmatigheld der verschijnselen altyd minder constant is, dan op een grooter terrein. Het zal wel net behoeven gezegd te worden, dat zullen dergelyke waarnemingen iets beteekenen, die niet over de honderden, maar over de duzenden en millioenen moeten genomen. 'worden, niet over weken of maanden, maar over meerdere jaren. Genomen gedurende den tijd van drie maanden over de be'volkng van een dorp van 1000 inwoners, zouden zij tot geene uitkomst hoegenaamd lerden. En toch, dat alles in aanmerking genomen, is het verschil hrer inderdaad luttel.

Immers terwijl het totaal huwelijken in Groningen, in het eerstgenoemde tijdvals bedroeg 280 gemıddeld jaarlijks, was dat in het volgende vijfjarige tijdvak gemiddeld per jaar ' 319 .

Daarnaar gerekend is de evenredıgheld, het eenige wat ons hier bezighoudt, als volgt:

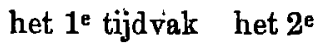

Tusschen jongmans en jonge dochters $77^{5}$ pCt. 75 pCt.

$\begin{array}{ccccc}" \text { " weduwen } & 4 & & 4 & \\ " \quad \text { weduwenaars en jonge dochters } & 13^{5} & & 15 & " \\ " \text { "weduwen } & 5 & & 6 & \end{array}$

Ík geloof dat men mij toestemmen zal dat ook hier weinig verschil bestaat.

Wij gaan verder.

Uit den volgenden staat $\mathrm{C}$, blijkt: dat het aantal mannen van beneden 30-jarigen ouderdom, gehuwd met vrouwen van eveneens beneden de 30 jaren heeft beloopen, jaarlijks gemıddeld gedurende $1850 / 54,471$, gedurende $1855 / 59,453$; met vrouwen van $30-45$ jaren, gedurende het eerste tijdvak gemiddeld 91 , het laatste 85 ; met die van 45 tot 60 jaren gemiddeld $1 \frac{2}{3}$ gedurende het eerste, 2 gedurende het laatste tijdvak.

Gaan wij over tot andere leeftijden, wij vinden telkens dezelfde constante eijfers. 
Om dat te doen uitkomen vestig $\mathrm{lk}$ de opmerkzaamheid op de omstandigheid, dat gedurende de jaren $1850 / 54$ gemiddeld jaarlijks 189 mannen van 30 tot 45 jaren huwden met vrouwen beneden de 30 jaren; in het daaropvolgende vijfjarige tijdvalk bedroeg dat 196 per jaar; - met vrouwen van gelijken leeftijd, in het eerste tijdvak 156 , in het tweede 172 ; met die van 45 tot 60 jaren, in beide tijdvakkeu min of meer hetzelfde aantal, t. w. in beide ongeveer 12 jaarlijks.

Klimmen $w 1$ hooger op, wij vinden dezelfde constante vaste reeks.

Van mannen van 45 tot 60 jaren huwden in de beide tijdvakken gemiddeld jaarlukss 11 met vrouwen van beneden 30 jaren, met die van 30 tot 45 jaren 36 , - met die van 45 tot 60 jaren 17 .

Sterker nog: van mannen van 60 jaren en daarboven, huwden, met weinig verschil in de beide tijdvakken, geljkk bugaande tabel $\mathrm{C}$ aandurdt, met vrouwen van beneden 30 jaren gemiddeld jaarlijks 1 , - met dre van 30-45 jaren gemıddeld jaarlijks $3,-$ met die van 45-60 jaren gemiddeld jaarlijks 4.

Neem den staat der huwelijken in het rijk, naar den ouderdom der vrouw, en gij vindt volgens tabel $D$ dat gemiddeld gedurende 1850/54 gehuwd zyn:

op 21-25 jarigen ouderdom $19 \mathrm{pCt}$; van 25 tot 30 jaren 36 pCt.;

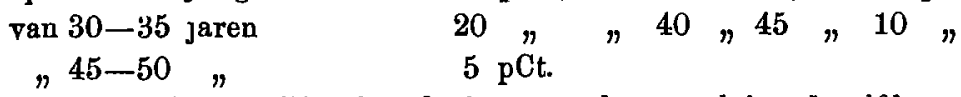

Gedurende de vijf volgende jaren vunden wij bijna dezelfde proportie terug, als van 21 tot 25 jaren $18 \frac{1}{2}$ pCt., voorts 34-21-12 en $6 \mathrm{pCt}$.

In een jaar en wel 1860 daarmede byjna geheel overeenstemmende. 18 pCt., 34-21-12 en 6 pCt.

$W_{1}$ l men meer bewijzen ? men werpe een blik op tabel $\mathbf{E}$, waar men zal vinden dat tegen 100 hertrouwde weduwenaren zijn hertrouwd: $1851 / 56$ gemıddeld 57 weduwen, 1857162 56 en dat op 100 overledene gehuwde mannen $d$ i. op 100 vrouwen die weduwen zyn geworden, zijn hertrouwd 1851/56 gemiddeld 23 weduwen, 1857/62 eveueens gemiddeld 23; voorts de vrij constante cyfers der huwelyksluitingen van 1815 tot en met 1864 in ons land, gelijk tabel $\mathbf{E}$ meer in het bijzonder aanduidt.

$W_{i j}$ zijn bij onze beschouwing der huwelijken eenigzins breedvoerig geweest, met het oog op de regelmatig terugkeerende toestanden, die men blijkens de ejjers in de bijgevoegde tabellen vindt.

$W_{1 j}$ vinden die echter ook op ander gebied. Of as het niet merkwaardig dat blyksens tabel F in Groungeu geboren werden in 1852/57 
gemiddeld 75 onechte kinderen per jaar, in $1858 / 63-76^{5}$, of wel in het eerste tijdvak 1 onecht op $13^{60}$ wettige, in het tweede 1 op $13^{12}$.

Neem de verhuizingen, tabel $G$.

Van het land naar de steden verhuisden, in verhouding tot het geheel der bijgekomenen, gedurende de jaren

$$
\begin{aligned}
& \text { 1853-56 gemiddeld } 34^{5} \text { pCt. } \\
& 1857-60 " 35 "
\end{aligned}
$$

Omgekeerd vertrokken van de 87 voornaamste gemeenten naar elders gemiddeld gedurende het eeıste tijdrak $33 \mathrm{pCl}$., het tweede $32^{25} \mathrm{pCt}$, terwijl de verhouding over het geheele rijk van het getal bujgekomenen bedroeg tegen dat der vertrokkenen:

$$
\begin{aligned}
& \text { in het eerste tijdvak } 95^{50} \mathrm{pCt} \text {. } \\
& " n \text { tweede } " 95^{25} "
\end{aligned}
$$

Verplaatsen wij ons, zegt Wagner, in den gocden ouden tijd, waamn fabelachtıge reısbeschrijvingen als die van Swift in zijne verhalen van Gulliver, meer in den smaak vielen dan thans, en stellen wij ons dan voor dat een schrijver, om zijne lezers iets nieuws op te disschen, de volgende beschrijving van een vreemd land of volk ontwierp.

„In dat land wordt ieder jaar door de wet bepaald hoevele paren huwen zullen, van welken ouderdom dooreen, hoevele jonge meisjes oude mannen, hoevele jonge mannen oude vrouwen bekomen, hoevele weduwnaars met weduwen zullen hertrouwen en zoo meer. Eene andere wet schrift voor het aantal personen, die het volgende jaar door zelfmoord een einde aan hun leven zullen maken. Eene derde wet bepaalt hoevele en welke misdaden in het volgende jaar zullen bedreven worden Een vierde, voegen wij er bij, schrijft voor viet alleen het aantal onechte kinderen 't welk het volgeude jaar zal geboren worden, maar ook de verhouding dier geboorten tot de wettigen In één woord, al die handelingen waarin wij vermeenen geheel vrij te zijn, om die al of niet te doen, worden In dien staat vooruit door de regernng vastgesteld en als eene wet in het Staatsblad opgenomen. En het volk gedraagt zich daarnaar en voert jaar op jaar de wetten getrouw uit. Bij het einde des jaars worden de tabellen opgemaalst en dan blijkt het dat de wetten werkelijk op de voorgeschrevene wijze uitgevoerd zijn. Wel komen her en daar kleine afwukingen roor, en blykt het dat deze of gene handelingen in een iets grooter of kleiner aantal voorvielen, als de wet voorgeschreven had; maar dat wordt weder daardoor goedgemaakt, dat in het budget der te doene handelingen het plus of minus 
op de rekening van het volgende jaar overgeschreven wordt, even als bij eene rekening-courant

Het volk van dat land 18 aan deze merkwaardige inrigting zoo gewoon, dat het daarin niets bijzonders meer ziet."

$W_{1 j}$ echter zouden in eene zoodange beschrijving van een rreemd volk de grootste Munchhausiade vinden, die wij ons denken kunnen. Ons zoude die toestand zoo onverdragelijk, zoo hoogst onnatuurlijk voorkomen, dat wij dien met den naam van onmogelijk bestempelen zouden. En inderdaad met het volste regt, wanneer wij ons dien denken als gedwongen door het staatsgezag. Geene magt ter wereld, vereenigde zij oostersch despotisme met Napoleontisme of Bismarcktısme, zoude zoodanige wet kunnen ten uitvoer leggen.

En toch het geschredt, en wel geheel vrijwillig. Wat ons zoude toeschijnen de grootste inbreuk te zijn op onze rrijheid en zelfstandigheid, zoo eene magt van buiten af ons daartoe zoude willen dwingen, geschiedt met eene regelmatigherd, die wij zelden bij de opvolging eener wet waarnemen. En hot merkwaardigste daarbij is, dat wij op die wijze fungeren als leden van een groot mechanisme en toch eene geheel vrije bewegıng bezitten, welke evenwel dat mechanisme volstrekt niet in zijn gang stoort.

$\mathrm{Nu}$ wordt er gezegd: dat zijn vaste wetten die de Maatschappij beheerschen; maar is dat wel juist, althans in den zin, waarin men spreekt van wetten der natuur?

Is het zoo zeker dat daar, waar men eene telkens terugkeerende regelmatigheid vındt, als b. $\nabla$. bij de huwelijken, sprake kan zijn van eene wet die onwederstaanbaar is, die dwingt zóó en niet anders te handelen. Ik geloof het niet. Wat men gewoon is wetten te noemen, zijn hoogstens regelmatigheden der op elkaar volgende verschijningen; doch de innerlyke wet dier versehjuning is ons nog onbekend.

Wanneer wij opmerken dat het aantal misdaden in alle landen min of meer gelijk blijkt, kan daar ran eene wet sprake zijn? Kan niet de werking die in gelıke getallen geuit wordt, de uitkomsten van zeer ongelıjksoortige bestanddeelen van verschillende toestanden zjjn? Waar zoude het heen, indren het jus st ware wat Dankwardt zegt in zijne verhandeling, over de vrijheid van den wil en de noodwendigheld onzer handelingen, "de menseh is onvrij, men "kan hem voor zijn doen evenmin verantwoordelyk stellen, als de "steen die, de wettes der zwaartelrracht volgende, op ons hoofd "nedervalt; de misdaad was de noodzakeluke werking eener 
"natuurwet. De wetten beheerschen niet, maar toonen slechts, op "welke gelijksoortge wjjze de oorzaken de verschijningen beheer„sehen." Doch daarom blijkt nog niet, dat de oorzaken der verselijningen bekend zijn. Het streven moet zijn die te verklaren.

Zoo is het bekend dat er bestendig eenige procenten meer jongens dan meisjes geboren worden. Dit staat zoo vast, overal waar men dat feit gadegeslagen heeft, dat wij het veilig beschouwen kunnen, als een vaste verhouding van oorzaak en gevolg. Doch waamn bestaat die? Hier staat een schrijver op die beweert dat de voeding der moeder van invloed is op het geslacht van het kind, dáár in het overgewigt van den ouderdom van den man boven dien van de vrouw. Aangenomen wat velen beweren, dat de laatste omstandigheid in vele gevallen daarvan de oorzaak $18, t$. w. dat een oude man met eene jongere vrouw gemiddeld meer zonen bekomt-zoo kan de statistrek daar geene verdere verklaring van geven, dan er op te wijzen dat het gebeurt.

Eerst wanneer het de physiologie gelukt ware, den invloed van den ouderdom der ouders, door de statistiek geconstateerd, met andere verwante verschjunngen in zamenhang te brengen, en die geheele reeks $\operatorname{van}$ verschijningen tot ééne gemeenzame hoogere oorzaak terug te brengen, kan elgenlıjk sprake zijn van eene wet. Het is dan dat waarschijnlyjkheid, hoogere waarschijnlijkhe1d verandert in zekerhe1d, dat men voorspellen kan. Wat men noemt wet van oorzaak en gevolg, dat namelijk reder con. sequent verbonden is aan eenig bijzonder antecedent, of antecedenten, het moet kunnen worden aangetoond, hoe en waarin die zamenhang bestaat. Het is een vereischte om te komen tot de kennis, dat eene gebeurtenis zal volgen, zoo lang een zekere toestand blijft bestaan, eene zekere omstandigheld blijft voorafgaan.

's Menschen handelıngen zijn afhankelijk van vele ook niterlyke physische factoren, als kliuaat, saizoen, weder; voorts van geslacht, van ouderdom, van sociale omstandigheden, als beschanng, beroep, stand, woonplaats en wat dies meer ejj. Daaruit vloelt dan voort volgens sommigen dat 's menschen wil en handelwize noodwendig en onvermijdelijk zijn. Daartegenover staat de leer dat onze wil niet bepaald wordt, gelijk andere verschijnselen, door antecedenten, maar zich zelf bepaalt, dat hij niet gehoorzaamt aan redenen of oorzaken, waaraan hlj onvoorwaardeljjk onderworpen 28.

Nu is het het woord "noodwendigheid" als vernederend voor de menscheljjke natuur, dat ons tegen de borst stuit. Daaronder moet alleen worden verstaan dit: gegeven de beweegredenen, die 
er voor iemand bestaan, gegeven het karakter, en den aanleg van het individu, zoo kan de wijze waarop hij in eenig gegeven geval zal handelen, met zekerherd worden afgeleid.

Kennen wij iemand gelijk men dat noemt, door on door, weten wij alle invloeden, die op hem kunnen inwerken, zoo zouden wij zijn gedrag met zooveel zekerhe1d kunnen voorspellen, als eenig natuurverschijnsel. De twijfel kan alleen ontstaan, dat men niet naauwkeurig met alle omstandigheden van eenig geval bekend is, doch zoo men dat is, maakt niemand bezwaar te zeggen: die of die zal in dat geval zoo handelen. Doch daarom wordt onze vrije wil daardoor in 't minst niet beperkt. Wij gevoelen er ons net te minder vrij door, dat die, welke ons van nabij kennen, verzekerd zijn, hoe wij in een voorkomeud geval zullen handelen. $W_{i j}$ beschouwen integendeel den twijfel wat ons gedrag zal zijn, als een bewijs van onbekendheid met ons karakter en vatten dat zelfs somtijds als eene beleediging op.

De leer dat onze wil, onze daden onveranderlyke gerolgen zijn van onzen voorafgaanden toestand des geestes, wordt noch door ons bewustzyn tegengesproken, noch voor onze natuur vernederend geacht.

$\mathrm{Nu}$ echter wordt de leer van oorzaak en gevolg toegepast op den wil, en zijne antecedenten in den regel opgevat als meer dan dat te bevatten. Velen gelooven niet, dat oorzaak en gevolg niet anders is dan eene reeks van aaneenschakelngen, die vast en onveranderlijk zijn. En toch is het zeker dat er daarom in het geval van den wil en onze daden geen geheim annige band is, die ons dwingt ons te bewegen als een marionet. $W_{1 j}$ weten dat wij niet als door eene tooverkracht gedreven, zóó moeten handelen en niet anders.

Wij gevoelen dat zoo wij wenschten te bewijzen dat wij de magt hebben, om eenigen op ons inwerkenden invloed te weerstaan, wij dat kunnen. Het zoude vernederend voor onzen trots en verlammend voor ons streven naar ontwikkelung en volmaking zijn, zoo wij anders dachten.

$\mathrm{Nu}$ is Mull van meening, dat zy, die beweren dat onze wil gehoel onafhankelijk is van eenig an tecedent, hoe ool genoemd, en dat elkeen jeder oogenblik kan handelen naar goeddunken, daartoe inzonderheid heen neigen, uit eene soort van instinktmatigen afkeer tegen het woord "noodwendigheid." Dat woord toch, in den gewonen zin, sluit in zich veel meer dan gelijkvormigheld van aaneenschakelingen, het beduldt "onwederstaanbaarheid."

Toegepast op den wil, geeft dat woord alleen te kennen, dat de gegeven oorzaak gevolgd wordt door hetgeen daarvan het uit- 
vloeisel is, evenwel onderherig aan alle mogelijke tegenwerking door andere oorzaken, waartegen het in de gewone beteekenis wil zeggen, "te sterk, te magtig om tegengewerkt te kunnen worden." Wanneer wij zeggen dat alle menschelijke handelingen noodzakelijk plaats grijpen, meenen wij alleen dat die zullen plaats grijpen, wanneer er niets tusschen beiden komt om die te voorkomen. Men moet niet uit het oog verliezen dat - gevallen van waanzin uitgezonderd - menschelijke handelingen bijna nimmer door eene beweegreden zoodanig absoluut beheerscht en gedwongen worden, dat er geen plaats meer overblyft voor den invloed van eenige andere; de oorzaken van welke de handelingen afhankehjk ziju, kunnen dientengevolge altijd nagegaan worden. Dat wat er gebeurt, niet anders had kunnen geschieden, tonzij er iets geschied ware in staat om het te voorkomen, zal voorzeker door nemand worden tegengesproken.

Maar dit "noodwendig" te noemen is dat woord te gebruiken in een zin, zoo verschillend van zijne oorspronkeljjke en gemeenzame meening, van dien welken het in de dagelijksche zamenleving heeft, dat het bijna een woordenspel mag genoemd worden

De leer, die wij voorstaan, onderseheidt zich daarin van die van het fatalisme, dat deze van meening is dat het niet kan baten zich daartegen te verzetten; dat het gebeuren zal, wat wij ook mogen doen om iets te voorkomen $\mathrm{W}_{\mathrm{j}} \mathrm{g}$ gelooven dat onze handelingen voortvloeijen uit ouze karakters en hetgeen men noemt onze organisatie, onze opleiding, de omstandigheden waarin wij verkeeren. Wij moeten begrijpen dat ons karakter niet voor, maar door ons gevormd is, dat het dientengevolge in onze eigene magt staat, dat te veranderen. Het karakter wordt gevormd door de omstandigheden waarin wij verkeeren, doch de weusch om het te wijzigen is eene van die omstandigheden, en wel eene van die, welke niet de minst invloedrijke is.

En juist het gevoel dat wij bezitten, dat wij in staat zijn ons karakter te wijzigen, zoo wy dat wenschen, is het gevoel van de zedelijke vrijheid, waarvan wij ons zelve bewust zijn. Hij is zedelıjk vrij, die het gevoel met zich omdraagt, dat zljne gewoonten en verzoekingen geen heerschappij over hem voeren en dat zoo hij den wensch koesterde om zich daarvan los te maken, daarvoor geen sterkere begeerte noodig was, dan waartoe hij zich zelf in staat acht. Het is natuurlık noodzakeljkk, om ons bewustzijn van vrijheid tot klaarheid te brengen, dat $w j$ er in geslaagd zijn om ons karakter zoodanig te vormen als wij tot dusverre beproefd hebben 
om het te vormen; want bijaldien wij hebben gewenscht en niet bereikt, hebben wij geene magt over ons eigen karakter, zijn wij niet vrij.

Het was een zeggen ran Locke, dat wij niet moeten vragen, of onze wil vrij is, maar of wij vrij zijn; want onze opvatting van vrijheid is de magt om overeenkomstig onzen wil te handelen, of m. a. w. de bewustheid, wanneer wij eene zekere wijze van handelen rolgen, dat wij eene andere hadden kunnen annemen zoo wij dat gewild hadden. Wij weteu dat wij in staat zijn eene wijze te volgen die onaangenaam is, in plaats van eene andere die zeer aangenaam zoude zijn; dat wij dus doende ons moeten inspannen en aanhoudend pogen op dien weg te blijven; dat elke verpoozing dier inspanning ons genoegen doet, en dat het mogelijk is, dat de beweegroden die ons noopt om op het pad der zelfverloochening voort te gaan, kan zijn een gevoel van regt, zonder uitzigt op belooning. Wij weten ook dat wanneer onze begeerten krachtig op onzen wil inwerken, onze wil wederkeerig op onze begeerten kan inwerken. Wij kunnen de kracht van onzen wil versterken door dien gestadig uit te oefenen. Wij kunnen de intensıtert van onze begeerten rerminderen door ons er aan te gewennen, die te onderdrukken, te bedwingen, in toom te houden. Wijkunnen door eon proces van geestelijke tucht het evenwigt onzer hartstogten veranderen, deze uitzoekende om die te voldoen en te ontwikkelen, andere onderdrukkende, ja geheel overwinnende en te niet doende. $W_{1 j}$ laten daar, of de begeerten niet soms te krachtig zijn, om daartegen bestand te wezen, maar meenen dit te mogen vaststellen, dat hij die aan de eene zijde de magt om te handelen overeenkomstig zijn wil, en aan de andere zijde de magt van zijn wil om zich vrij te makeu van de heerschappij van pijn of genoegen heeft verwezenlijkt, waarschijuljjk de grens der vrijherd bereikt heeft.

$W_{\mathrm{ij}}$ drukken dat aldus urt: „onze wlsbepaling is het gevolg van drijfveeren, die volgens zekere wetten werken, en op haur beurt door voorafgaande drijfveeren veroorznakt zijn."

De toepassing nu van deze beginselen op de regelmatig terugkeerende toestanden geljik de statistiek ons die leert kennen, is met moeijelijk.

Zoo blykt bijo. dat eene zekere temperatuur de kracht eener hartstogt doet toenemen, m. a. w. de verzoeking tot eene zekere ondeugd, en wordt aangetoond dat met cene rijzende temperatuur de ondeugd toeneemt, omgekeerd bij eene dalende afneemt. Jaar op jaar doen zıch dezelfde verschijnselen voor. Daaruit blijkt dat de mensch onder den invloed van uiterlyke omstandigheden staat, 
doch niet zoo, dat hij er zich niet tegen verzetten kan. Wat men opmerkt is dat de verhoudingen ongeveer dezelfde blijven, evenals de toestand, waarin men die waarneemt, ook min of meer dezelfde blijft.

Doch uu wordt er eene belangrijke greep gedaan in de bekende of waarschijnlijke oorzaken, welke geheel of ten deele dien toestand veroorzaken; b. v. bestond er in eenige stad eene naauwkeurige statistiek van de dronkenschap, het is waarschijnlijk dat men ook daar, gelijk in zoorele andere zalsen als hierboven aangetoond, vrij regelmatig dezelfde cijfers ieder jaar gemiddeld zoude zien terugkeeren.

Doch daarom behoeft men niet te zeggen: dus is een zooveelste gedeelte der bevolking gedoemd tot dronkenschap; het tegendeel is waar. Het zal zoo blijren zoolang de toestand onveranderd blijft.

Gebrek aan onderwijs, aan opleiding, armzalige woningẹn, onbekendheid met wat ik wll noemen, „behoefte aan geestelijk voedsel”, slechte verdıensten en karige loonen, ja wat al niet meer, zijn als zoovele oorzaken te beschouwen, die vrij zeker, zoolang die blijven voortduren, hetzelfde aantal dronkaards zullen produceren. Doch nu, komt er verandering. Een volgend geslacht bekomt betere opleiding en ontwikkeling, ik wil eens nemen tengevolge van onze zoogenaamde lagere burgerschool, leert dus andere behoeften kennen, wordt beter onderlegd voor eenig valk of bedrijf, heeft dus meer kans vooruit te komen; hij treedt in de maatschappij en vindt daar hulpbanken en andere gelegenheden om hem te steunen, weder eene andere vereeniging zorgt voor betere woningen enz. Na kan dat geslacht, ja ook nog wel dronkaards leveren, maar $1 \mathrm{k}$ ben er zeker van, minder dan het vroegere 't welk al die voordeelen miste. Mag men dus daar niet zeggen, dat de mensch daarop kan inwerken net alleen, maar ook dat de wil wordt beheerscht, in dezen ten goede, door voorafgegane antecedenten. De statistiek der dronkenschap zal ons andere cijfers leeren, waardoor ${ }^{2}$ doordien invloeden, die daarop uttwerking hebben, tegenovergesteld zijn aan de vroegere.

Mijn blyk valt op eene statistiek der in 1853 in Nederland ultgekomen boekwerken.

Ik vind daar dat het aantal bedraagt 1938 , waarionder alleen over godgeleerdheld 561, dus meer dun $\frac{1}{4}$, en dan darrvan wat genoemd wordt praktische godgeleerdheid, elgenlık hoofdzakelijk preken 367, dus bijna $\frac{1}{5}$ van het totale cijfer over alle vakken van wetenschap, kunst, letterkunde enz.

Ik mag hier gerust zeggen dat $1 \mathrm{k}$ die verhoudıng niet wenschelijk vind, Fene preek is voorzeker eene zeer hellyamo lektuur, doch 
of het peil, warrop het meerendeel stond van de 367, die in 1853 het licht zagen, wel zoo hoog was dat het met der daad geestelijk roedsel kan worden genoemd, ben ik zoo vrij to betwijfelen. En toch geloof ik dat wanneer men meer elfers van den boekhandel dezer jaren had, dat die al weinig uiteen zoude loopen.

Doch daarom behoeft het volk van Nederland net altijd hetzelfde aantal preken te verduwen.

Voorzeker, zoolang de toestand van onderwijs en ontwikkeling zoo blijft als in die tijden, zal ook de lektuur daarvan de blijken dragen, doch nets belet daarop invloed uit to oefenen, en ik houd mij verzekerd dat eene statistiek van den boekhandel van hotjaar 1868 reeds andere verhoudingen aan de hand zal geven. Nu is het zeker dat de mensch vrij bluft om zoovele preken te lezen als hij verkiest en toch kan het niet uitblijven of eene meer algemeene wetenschappelijke opleiding des rolks, moet noodzakelyk verandering in zijne dagelijksche lektuur ten gevolge hebbe.

Uit eene statistiek vóór twee jaren uitgegeven van de moorden jn ouderscheidene landen blijkt dat vrij geregeld jaarlıks in Engeland ééne moord gepleegd wordt op ongeveer 600,000 inwoners; in Spanje 1 op 4000 , in den Romeinschen staat 1 op 750 inwoners.

Daaruit blıkt vrij durdelijk de toestand dier landen, doch daarom vloeit daaruit volstrekt niet voort, dat die zoo blijven moet, en dat, iets toegegeven aan de misschien meer wraakgienge natuur van de bewoners der zuideljke landen, daarin niet eene verandering ten goede kan worden bewerkt.

In Engeland heeft het Fenianisme deze cijfers reeds geheel omver gew orpen.

Het aantal zelfmoorden in de stad Londen, heeft in de laatste zeven jaren gevarieerd $\operatorname{van} 251$ tot 267.

Zoo vinden wij in den regel in Nederland 1 onechte op 19 wettige geboorten, waarvan in de steden 1 op de 11 , ten platten lande 1 op de 37. In Stiermarken en benedeu-Oosteurijk 1 op de 4 . In Weenen 1 op de 2 geboorten, 't ergst in Rome 3 onechte op 4 geboorten. In Mecklenburg in 18451 op de 5 , in 18521 op de 4 . De bevolking te lande is daar echter nog grondhoorig, en wordt bij ouderdom of gebreken, armlastig ten laste van den grondeigenaar. Van daar dat de landheer het regt heeft, het sluiten van een huwelijk aan zijne onderhoorigen te wergeren. Een der gevolgen van dien maatregel is, dat het paartje eenvoudig de formaliterten overslaat. Daarentegen vindt men in Nederland 1 huweljjk op de 137 in- 
woners; in de genoemde Oostenruksehe landen 1 op de 190. Hoe zouden die cijfers veranderen, zoo de wetgeving zıch meer de belangen des volks aantrok!

Wat hebben wij hierboven gezien?

Men zegt wel eens "de huweljken worden in den hemel gesloten."

Wij hebben gezien dat de verhouding der gehuwde paren bijna altijd jaren aanéén overanderd bleef, dat hetzelfde aantal huweljjken gesloten werd tusschen jongmans en jonge dochters, weduwenaars en weduwen, tusschen ouden en jongen.

Men zoude daarin ligt een bewijs kunnen zien, dat dat alles vooraf zoo verordonneerd was, en dus het gezegde spreekwoord waarheid bevatte.

$\mathrm{Nu}$ komt het mij voor dat in gewone jaren, waarn geene epidemien heerschen, geen krijg gevoerd, geen misgewas plaats gehad heeft aan de eene zijde, en an de andere zude geen groote maatregelen genomen zijn die op de volkswelvaart een belangrijken invloed uitoefenen, in één woord, het eene jaar vrij wat geljk is aan het andere, de productie en consumtie min of meer dezelfdo uutkomsten ten gevolge moeten hebben. En daaronder is ook de sterfte van mannen en vrouwen; van daar al wederom hetzelfde aantal weduwnaars en weduwen, van welke, gelık wij gezien hebben, ecn zeker bepaald aantal dan wederom voor het altaar verschijnen.

Dat is dujdelijk, wanneer men enkele butengewone jaren afzonderlyk onderzoekt, geljjk tabel $\mathrm{E}$ aanduidt.

Daar vinden wij gemiddeld in 1815/24 1 huwcluk op 126 inwoners, doch in het jaar 1815 alleen 1 op 103, welk grooter cijfer moet worden toegeschreven aan de rust, die het land, met urtzonderıng der 100 dagen, na zoovele rampspoedige jaren genoot.

Zoo vinden wij in 1825/34 gemiddeld 1 op de 134 .

$$
\begin{aligned}
& \text { doch in } 1831 \text { slechts } 1 \text { op } 180 . \\
& \text { " } 1832 \text { " } 1 \text { " } 165 .
\end{aligned}
$$

gevolgen van onzen tweespalt met Belgie, en het onder de wapenen verschijnen van zoovele soldaten en schutters; daarentegen in 1834 en 1835 , toen mun weder eenigzins ter verademing $\mathrm{kwam}, 1$ op de 117 en 1 op de 111.

in $1845 / 54$ gemiddeld 1 op 130 , doch in \begin{tabular}{llll|l}
1846 & 1 & op & de & 148 \\
1847 & 1 & $\#$ & 158
\end{tabular} jaren van duurte. in 1850 echter reeds weder 1 op de 112 $1851 " n, 1$ " 1116 bewijs dat na jaren vau weınig huwelijken, de volgende het weder 
goedmaken, en wij zoo over grootere tijdvakken altijd op het gemiddelde cijfer terugkomen.

$B$ j de geregtelijke statistiek vinden $w i j$ in strafzaken eene niet onbelangruke afneming gedurende de jaren 1860/64, in vergeluking met de vijf voorafgegane, wat, zoo die cijfers juist zijn, eene heuglijke verschijning zoude ziju.

Opmerkelık zija de zoo constante cijfers die wij gedurende vier achtereenvolgende jaren bij de kantongeregten waarnemen; hetzelfde aantal overtredingen van Provinciale Reglewenten, van plaatselyke verordeningen: bewijs dat hetzelfide aantal ingezetenen gestraft is wegens het net schoonhouden van afwatermgen, het niet op vrijdag schrobben der klunkers, het ophangen of bleeken van waschgoed. Wat beduidt dat anders, dan dat dezelfde daden van achteloosheld die in de jaren 1860 en 1861 voorkwamen, ook wederom in de beide daaroprolgende jaren begaan werden.

Zoo vinden wy alle 4 jareu juist wederom dezelfdo verhouding van de enkele diefstallen, vallende onder art. 401 van het wetboek van strafzaken, als van te veldstaande vruchten, mest, reet, plaggen, zoden enz. (voorzien bij art. 18 der wet van 29 Juny 1854) : bewje dat min of meer hetzelfde antal personen de verzoeking net hebben kunnen weerstaan.

Doch daarom behoeft dat niet zoo te blijven, integendeel bij ultbreiding van onderwijs en welvaart, moet ook die verhouding veranderen.

Wat de mensch vermag om den maatschappelijken toestaud te wijzigen, blykt overtugend uit de uitwerkselen van het in Engelaud ungevoerde stclsel van vrijen handel.

De officieele waarde van den invoer, die in 184265 millioen pd. st. bedroeg, was in 1858 tot 138 mill pd. geklommen; de uitvoer van 47 tot 116 mll. pd. en dus beide meer dan verdubbeld.

In 1842 werden 129,000 ton schepen gebouwd, in 1858208,000 ton.

In 't laatst van 1842 bedroegen de in de engelsche bank nedergelegde gelden eene som van 9 millioen pd., en in 't laatst van 1858 van meer dan 20 millioen pd.

In 1842 bedroeg in Engeland het getal in staat van beschuldiging gestelde personen 31,300 , in 1858 was dat gedaald tot 17,800

In 1842 bedroeg het kapitaal der spaarbanken $25,000 \mathrm{pd}$. en in 185836,000 pd. Ik weet wel wat men tegen deze cijfers zoowel als tegen meerdere door $\mathrm{m}$ j gebezigde kan aunvoeren, dat die niet altijd boven alle bedenking verheven zijn, dat die vooral bij onderlınge vergelıkingen niet altujd den toets der warheld 
kunnen doorstaan, dat maar al te veel hgtvaardig wordt aangenomen, wat door anderen, zonder nadenken bijeengebragt 18: voor het doel echter waartoe ik die noodig had, geloof jk dat ze als voldocnde bewijzen dienen mogen.

Voorzeker sprekende bewijzen van 's menschen invloed. Ik weet dat ook andere omstandigheden daartoe zullen hebben medegewerkt, dat b. $v$ wat de in staat van beschuldigng gestelde personen betreft, daarop ook eene wijziging van de strafwetgeving die in 1855 plaats gehad heeft, met zonder in rloed is geweest, doch daartegenover staat dat daarbij niet uit het oog moet verloren worden, dat un die 16 jaren de bevolking met meer dan 3 mulloeen is vermeerderd.

Ik vermeen hiermede te kunnen volstan en voldoende door redenering en feiten te hebben aangetoond, dat, welke regelmatig terugkeerende toestanden de statistiek ons ook an de hand geeft, 's menschen vrije wul daardoor rolstrekt niet opgeheven wordt; dat die wel veel door voorafgaande antecedenten bepaald wordt, doch dat het in 's menschen vermogen staat, daarop in te werken en, dat gedaan hebbende, met vrij wat zekerheid te kunnen voorspellen, dat daarop ook andere uitkomsten zullen volgen.

Het is zoo waar, zegt Mill, in zijn Utılitarianism, dat niemand er aan twifelen kan dat veel van het positieve kwaad in de wereld kan opgeruımd worden, dat alle groote bronnen van menschelyk lijden door menschelijke zorg eu unspanning kunnen worden overwonnen, en alle, zoo men zich slechts op doorgando verbetering wilde toeleggen, tot engere grenzen beperkt.

Inderdaad hoe geheel anders zoude het aanschijn des aardryks wezen, byaldien, om ons slechts tot deze eeuw te bepalen, zij die de lotgevallen der volkeren besturen, minder zelfzuchtige oogmerken maar meer het algemeen belang op elk gebied in den uitgebreidsten zin des woords op het oog gehad hadden.

Neem eens aan dat na de fransche revolutie de volkeren van Europa, voor zooverre zij daarvoor rijp waren, eene constitutie hadden bekomen als die, welke wij bezitten;

dat in plaats van bescherming, de banier van den vrijen handel omhoog geheven ware;

dat die niet te tellen milhoenen nu door de staande legers verslonden, aan voortbrengenden arbeld gewijd, de armen en hoofden daarmede bezig geweest, zich met nuttigen arbeid onledig gehouden hadden;

dat un plrats van het volk diets te maken dat godsdienst be- 


\section{1}

staat in ijdele ccreroonien, ware ontwikkeling des menschen, gelijk wij hier gelegenheid hebbeu van onze kansels te hooren rerkondigen, ware gepredikt geworden; dat in plaats ván de uitingeu vau 's menschen geest te smoren en te verdooven, allomme vrijheid van drukpers geheerseht hadde;

wie toch twijelt daaraan, of de 'statistiek zoude ons op elk gebied geheel andere cijfers hebben leeren kennen, dan die welke wij daar thans aanschouwen.

Zoo waar is het wat Quételet zegt:

"En considérant les choses sous ce point de vue, on concevra mieux la haute mission du légıslateur, qui tient en quelque sorte entre ses mains le budget des orımes, et qui peut en diminuer ou en augmenter le mombre par des mesures combinés avec plus ou moins de prudence."
Groningen, 1868 .
H. A. Wijnne. 
Tabel A.

Op de 1000 huwelyken werden voltrokken:

\begin{tabular}{|c|c|c|c|c|}
\hline 'T RIJK. & $\begin{array}{c}\text { Tusschen } \\
\text { jongmans en } \\
\text { jonge } \\
\text { dochters. }\end{array}$ & $\begin{array}{c}\text { Jongmaus en } \\
\text { weduwen. }\end{array}$ & $\begin{array}{l}\text { Weduwnaars } \\
\text { en jonge } \\
\text { dochters }\end{array}$ & $\begin{array}{l}\text { Weduwnaars } \\
\text { en weduwen. }\end{array}$ \\
\hline $\begin{array}{c}1850 \\
1851 \\
1852 \\
1853 \\
1854 \\
\text { Gemıddeld } 50 / 54 \\
1855 \\
1850 \\
1857 \\
1858 \\
1859 \\
1860 \\
\text { Gemıddeld } 55 / 59\end{array}$ & $\begin{array}{l}757.7 \\
78635 \\
800.8 \\
8086 \\
791.2 \\
78851 \\
790.8 \\
778.5 \\
793.1 \\
7797 \\
777.5 \\
768.1 \\
783.45\end{array}$ & $\begin{array}{l}56.7 \\
50.9 \\
468 \\
47.8 \\
479 \\
4928 \\
487 \\
49.5 \\
47 \\
47.2 \\
493 \\
498 \\
483\end{array}$ & $\begin{array}{l}133 \\
116.2 \\
1124 \\
106 \\
117.6 \\
11682 \\
117.7 \\
125 \\
1149 \\
1259 \\
126.1 \\
13062 \\
121.45\end{array}$ & $\begin{array}{l}52.3 \\
44.9 \\
37.9 \\
35.9 \\
40.4 \\
4166 \\
40.6 \\
45.2 \\
43 \\
45 \\
45.2 \\
50.8 \\
43.60\end{array}$ \\
\hline
\end{tabular}

TABel B.

Huwelijken tusschen:

\begin{tabular}{|c|c|c|c|c|}
\hline STAD GRONINGEN & $\begin{array}{l}\text { Jongmans } \\
\text { en jonge } \\
\text { dochters. }\end{array}$ & $\begin{array}{l}\text { Jongmans en } \\
\text { weduwen }\end{array}$ & $\begin{array}{c}\text { Weduwmaars } \\
\text { en jonge } \\
\text { dochters. }\end{array}$ & $\begin{array}{l}\text { Weduwnaars } \\
\text { en wedurven }\end{array}$ \\
\hline $\begin{array}{c}1852 \\
1853 \\
1854 \\
1855 \\
1856 \\
1857 \\
\text { Totaal 52157 } \\
\text { Gemidd. " } \\
1858 \\
1859 \\
1860 \\
1861 \\
1862 \\
1863 \\
\text { Totaal 58/63 } \\
\text { Gemidd. " }\end{array}$ & $\begin{array}{r}180 \\
241 \\
218 \\
218 \\
241 \\
180 \\
1303 \\
217 \\
-- \\
224 \\
241 \\
238 \\
245 \\
210 \\
269 \\
1427 \\
238\end{array}$ & $\begin{array}{r}13 \\
8 \\
10 \\
11 \\
9 \\
17 \\
68 \\
11 \\
9 \\
16 \\
12 \\
21 \\
11 \\
11 \\
80 \\
13\end{array}$ & $\begin{array}{r}26 \\
34 \\
41 \\
34 \\
44 \\
47 \\
226 \\
37 \\
48 \\
49 \\
59 \\
46 \\
41 \\
45 \\
288 \\
48\end{array}$ & $\begin{array}{r}16 \\
17 \\
16 \\
11 \\
17 \\
13 \\
90 \\
15 \\
-11 \\
12 \\
23 \\
29 \\
18 \\
19 \\
122 \\
20\end{array}$ \\
\hline Totaal 52/63 & 75 pCt. & 4 pCt. & $15 \mathrm{pCt}$ & 6 pCt. \\
\hline
\end{tabular}


Tabel ${ }^{\circ} \mathrm{C}$.

'т RIJK Bij eene paarsgewijze indeeling naar den ouderdom verkrijgt men de volgende urtkomsten: (op de 1000).

\begin{tabular}{|c|c|c|c|c|c|c|c|c|}
\hline & & & 1850. & 1851. & 1852. & 1853 & 1854. & 1855 \\
\hline $\begin{array}{l}\text { Mannen beneden } \\
\text { de } 30 \text { jaren met } \\
\text { vinuwen . . . . }\end{array}$ & $\begin{array}{l}\text { lieneden } \\
\text { van } \\
\text { ") }\end{array}$ & 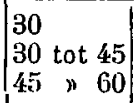 & $\begin{array}{r}476.3 \\
88: 3 \\
27\end{array}$ & $\begin{array}{r}481.2 \\
88.6\end{array}$ & $\begin{array}{r}475 \\
923 \\
25\end{array}$ & $\begin{array}{r}473.43 \\
9568 \\
2.25\end{array}$ & $\begin{array}{r}45311 \\
93.44 \\
2.01\end{array}$ & $\begin{array}{r}450.34 \\
87.22 \\
261\end{array}$ \\
\hline $\begin{array}{l}\text { Mannen van } 30 \\
\text { tot } 45 \text { jaren met } \\
\text { vouwen } .\end{array}$ & $\begin{array}{l}\text { beneden } \\
\text { van } \\
\text { " }\end{array}$ & $\left|\begin{array}{l}30 \\
30 \text { tot } 45 \\
45, " 60\end{array}\right|$ & $\begin{array}{r}1802 \\
1558 \\
128\end{array}$ & $\begin{array}{r}1856 \\
1554 \\
115\end{array}$ & $\begin{array}{r}190.6 \\
1534 \\
122\end{array}$ & $\begin{array}{r}19239 \\
153.92 \\
1119\end{array}$ & $\begin{array}{r}20054 \\
16257 \\
11.99\end{array}$ & $\begin{array}{r}193.18 \\
174.18 \\
1258\end{array}$ \\
\hline $\begin{array}{l}\text { Mammen van } 45 \\
\text { tot } 60 \text { jaren met } \\
\text { vrouwen } . .\end{array}$ & $\begin{array}{l}\text { beneden } \\
\text { van } \\
\text { " }\end{array}$ & $\left|\begin{array}{l}30 \\
30 \text { tot } 45 \\
45 \geqslant 60\end{array}\right|$ & $\begin{array}{l}132 \\
38.9 \\
207\end{array}$ & $\begin{array}{l}10.8 \\
356 \\
185\end{array}$ & $\begin{array}{l}10.3 \\
352 \\
17.7\end{array}$ & $\begin{array}{l}1025 \\
3459 \\
15.85\end{array}$ & $\begin{array}{l}1262 \\
35.76 \\
17.19\end{array}$ & $\begin{array}{l}12.11 \\
34.06 \\
16.89\end{array}$ \\
\hline $\begin{array}{l}\text { Mannen van } 60 \\
\text { Jacu en daarboven } \\
\text { met vrouwen. . . }\end{array}$ & $\begin{array}{l}\text { beneden } \\
\text { van } \\
n\end{array}$ & $\left|\begin{array}{l}30 \\
30 \text { tot } 45 \\
45,60\end{array}\right|$ & $\begin{array}{l}1 \\
3.4 \\
4.6\end{array}$ & $\begin{array}{l}1 \\
3 \\
4.7\end{array}$ & $\begin{array}{l}11 \\
32 \\
4.4\end{array}$ & $\begin{array}{l}0.94 \\
2.78 \\
4.41\end{array}$ & $\begin{array}{l}1.09 \\
335 \\
390\end{array}$ & $\begin{array}{l}150 \\
389 \\
432\end{array}$ \\
\hline & & & 1856. & 185\%. & 1858. & 1859 & 1860. & \\
\hline $\begin{array}{l}\text { Nannen boneden } \\
\text { de } 30 \text { jaren met } \\
\text { vrouwen . . }\end{array}$ & $\begin{array}{l}\text { beneden } \\
\text { van } \\
\text { }\end{array}$ & $\left|\begin{array}{lll}30 & \\
30 \text { tot } & 45 \\
45 & 00\end{array}\right|$ & $\begin{array}{r}45387 \\
83.15 \\
212\end{array}$ & $\begin{array}{r}456.68 \\
8520 \\
166\end{array}$ & $\begin{array}{r}44879 \\
84.66 \\
163\end{array}$ & $\begin{array}{r}456.77 \\
8103 \\
287\end{array}$ & $\begin{array}{r}44978 \\
77.54 \\
1.63\end{array}$ & \\
\hline $\begin{array}{l}\text { Mannen van } 30 \\
\text { tot } 45 \text { Jaren met } \\
\text { vrouwen. }\end{array}$ & $\begin{array}{l}\text { beneden } \\
\text { van } \\
\text { " }\end{array}$ & $\left|\begin{array}{l}30 \\
30 \text { tot } 45 \\
45 》 60\end{array}\right|$ & $\begin{array}{r}20230 \\
16696 \\
14.04\end{array}$ & $\begin{array}{r}197.65 \\
17060 \\
1137\end{array}$ & $\begin{array}{r}195.65 \\
175.16 \\
1329\end{array}$ & $\begin{array}{r}19614 \\
17340 \\
11.85\end{array}$ & $\begin{array}{r}195.55 \\
17803 \\
12.65\end{array}$ & \\
\hline $\begin{array}{l}\text { Mannen van } 45 \\
\text { tot } 60 \text { jaren met } \\
\text { vrouwen . . . }\end{array}$ & $\begin{array}{l}\text { beneden } \\
\text { van } \\
\end{array}$ & $\left|\begin{array}{l}30 \\
30 \text { tot } 45 \\
45 * 60\end{array}\right|$ & $\begin{array}{l}10.81 \\
3693 \\
17.71\end{array}$ & $\begin{array}{l}11.10 \\
3684 \\
17.80\end{array}$ & $\begin{array}{l}11.73 \\
3827 \\
18.30\end{array}$ & $\begin{array}{l}10.22 \\
37.18 \\
1796\end{array}$ & $\begin{array}{l}11.69 \\
39.99 \\
20.95\end{array}$ & \\
\hline $\begin{array}{l}\text { Mannen van } 60 \\
\text { Jaren en daarboven } \\
\text { met vrouwen }\end{array}$ & $\begin{array}{l}\text { beneden } \\
\text { van } \\
\text { " }\end{array}$ & $\left|\begin{array}{lll}30 & \\
30 & \text { tot } & 45 \\
45 & y & 60\end{array}\right|$ & $\begin{array}{l}1.10 \\
4.12 \\
4.61\end{array}$ & $\begin{array}{l}1.04 \\
3.16 \\
443\end{array}$ & $\begin{array}{l}083 \\
4.33 \\
4.59\end{array}$ & $\begin{array}{l}1.07 \\
370 \\
4.92\end{array}$ & $\begin{array}{l}089 \\
1.29 \\
362\end{array}$ & \\
\hline
\end{tabular}

Gemiddeld:

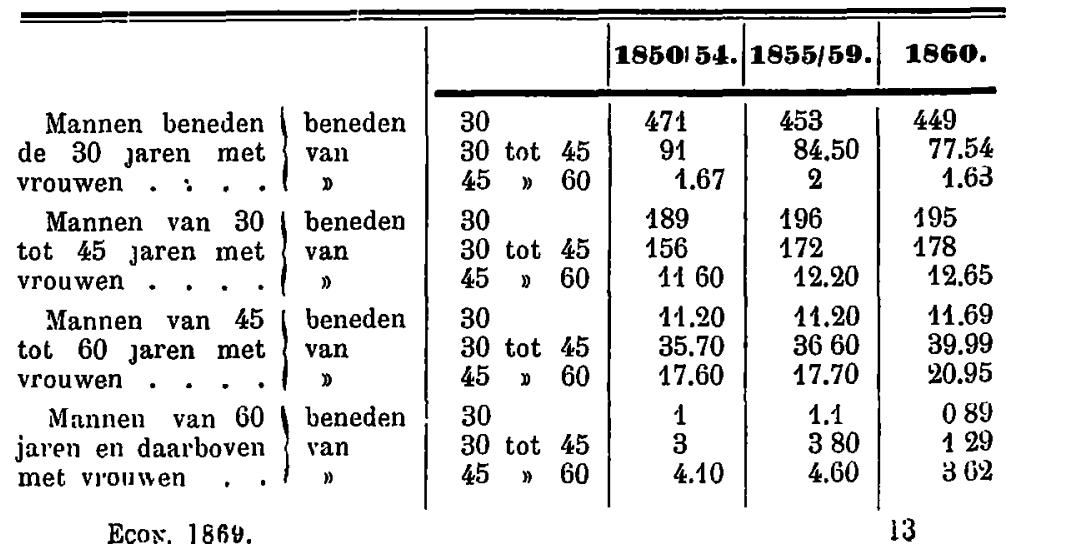

Ecos, 1869. 
TABEL D.

STAAT DER HUWELIJKEN naar den ouderdom in het rigk.

\begin{tabular}{|c|c|c|c|c|c|c|c|c|}
\hline & $\sum_{0}^{\vdots}$ & 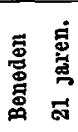 & 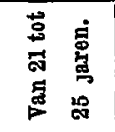 & 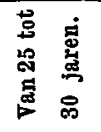 & 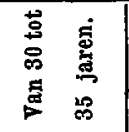 & 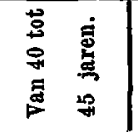 & 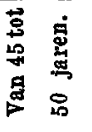 & 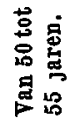 \\
\hline 1850 & 27386 & 504 & 5144 & 9890 & 5312 & 2700 & 1545 & 1041 \\
\hline 1851 & 26.768 & 461 & 5207 & 9637 & 5448 & 2558 & 1435 & 882 \\
\hline 1852 & 25.530 & 426 & 5016 & 9108 & 5237 & 2515 & 1344 & 809 \\
\hline 1853 & 24487 & 400 & 4741 & 8851 & 5190 & 2380 & 1186 & 754 \\
\hline 1854 & 23855 & 376 & 4313 & 8398 & 5177 & 2427 & 1350 & 784 \\
\hline Gemidd. $50 / 54$ & 25.605 & 433 & $\begin{array}{c}4884 \\
19 \mathrm{pCt} .\end{array}$ & $\begin{array}{c}9177 \\
36 \text { pCt. }\end{array}$ & $\begin{array}{c}5273 \\
20 \text { pCt. }\end{array}$ & $\begin{array}{c}2516 \\
10 \mathrm{pCt} .\end{array}$ & $\begin{array}{l}1372 \\
5 \text { pCt. }\end{array}$ & 854 \\
\hline 1855 & 23.367 & 342 & 4282 & 8000 & 5193 & 2466 & 1342 & 721 \\
\hline 1856 & 24.509 & 332 & 4462 & 8442 & 5268 & 2640 & 1496 & 812 \\
\hline 1857 & 25950 & 400 & 4793 & 8913 & 5465 & 2758 & 1635 & 888 \\
\hline 1858 & 26.342 & 369 & 4954 & 8773 & 5495 & 2969 & 1664 & 949 \\
\hline 1859 & 27.007 & 429 & 4968 & 9207 & 5622 & 3043 & 1640 & 920 \\
\hline Gemidd. $55 / 59$ & 25435 & 374 & $\begin{array}{c}4691 \\
18 \frac{1}{2} \text { pCt. }\end{array}$ & $\begin{array}{c}8663 \\
34 \text { pCt. }\end{array}$ & $\begin{array}{c}5409 \\
21 \mathrm{pCt} .\end{array}$ & $\begin{array}{c}2775 \\
\text { bujna } 11 \%\end{array}$ & $\begin{array}{l}1555 \\
6 \mathrm{pCt} .\end{array}$ & 858 \\
\hline 1860 & 27.108 & 383 & $\begin{array}{c}4874 \\
18 \text { pCt. }\end{array}$ & $\begin{array}{c}9079 \\
34 \text { pCt. }\end{array}$ & $\begin{array}{c}5618 \\
\text { byjna } 21 \%\end{array}$ & $\begin{array}{c}3211 \\
12 \text { pCt. }\end{array}$ & $\begin{array}{l}1647 \\
6 \mathrm{pCt} .\end{array}$ & 1062 \\
\hline
\end{tabular}

Tabel E.

Mr. W. T. Sandberg, bl. 587, B Błbled Economist 5e aflevering 1866.

Op 100 hertrouwde weduwenaren zujn hertrouwd weduwen

$$
\begin{array}{lll}
1851 / 56 & \equiv & 57 \\
1857 / 62 & = & 567
\end{array}
$$

op 100 overleden gehuwde mannen d. 1 . op 100 vrouwen, die weduwen zujn geworden, zujn hertrouwd weduwen:

$\begin{array}{ll}1851 / 56 & 228 \\ 1857 / 61 & 231\end{array}$

Huwelykssluitingen tot het getal inwoners als 1 tot:

$\begin{array}{cccc}1815 / 24 & \text { gemiddeld jaarlylks } & 126.5 \\ 1825 / 34 & \# & \# & 134.1 \\ 1835 / 44 & \prime & n & 128.1 \\ 1845 / 54 & \prime & n & 139.1 \\ 1855 / 64 & " & n & 128.6\end{array}$

Eenige jaren wijken van het middencyfer af b. v.

$$
\begin{array}{lll}
1815 & 1 & : 103 \\
1831 & 1 & : 180.6 \\
1832 & 1 & : 165
\end{array}
$$

van daar het lagere gemiddelde cljfer van $1825 / 34$

$$
\begin{array}{ll}
1846 & 1: 148.3 \\
1847 & 1
\end{array}
$$

vandaar het hoogere gemiddelde cufer van 1845/54, dat alles in aanınerking genomell, die cyfers ury constant, herstelt zich, zoo ook

$$
\begin{array}{ccccc}
\text { in } & 1834 & 1 & \text { op } & 117 \\
n & 1835 & 1 & n & 111 \\
n & 1850 & 1 & n & 112 \\
n & 1851 & 1 & \text { ” } & 116
\end{array}
$$


Tabel F.

Verhouding der onechte tot de wettige geboorten in Groningen :

1852
1853
1854
1855
1856
1857
Totaal $1852 / 57$
Gemiddeld "
"

1858
1859
1860
1861
1862
1863

Totaal $1858 / 63$ Gemiddeld "

TABEL H.

\begin{tabular}{ccc}
\multicolumn{2}{c}{ Geboren } \\
\cline { 3 - 3 } Wettig & & Onecht. \\
1038 & 87 \\
997 & & 74 \\
995 & & 52 \\
1009 & & 71 \\
1011 & & 81 \\
1065 & & 87 \\
& & \\
6115 & & 452 \\
1019 & & 75 \\
1360 & op & 1 \\
& & \\
983 & & 92 \\
956 & & 88 \\
845 & & 46 \\
1124 & & 95 \\
1001 & & 63 \\
1112 & & 76 \\
& & \\
6021 & & 460 \\
1004 & & $76^{5}$ \\
1312 & op & 1
\end{tabular}

GEREGTELIJKE STATISTIEK. Staatk, paarboekge 1863, bladz. 186.

Kantongeregten.

Beklaagden.

\begin{tabular}{|c|c|c|c|c|c|c|c|}
\hline 1860 & Mannen & 83 pCt. & Vrouwen & 17 pCt. & beneden & 16 jaren & $7 \mathrm{pC}$ \\
\hline 1861 & $n$ & $83 n$ & $n$ & $17 》$ & $n$ & $16 》$ & $6 \%$ \\
\hline 1862 & $n$ & 84 & $n$ & 16 & $n$ & 16 & 7 \\
\hline 186 & $\eta$ & 84 & $n$ & 16 & $"$ & 16 & 8 \\
\hline
\end{tabular}

Verhouding der veroordeelden met opzigt tot den aard der gepleegde misdrijven :

Overtreding Code Penal of andere wetten. Maatregélen van inwendig bestuur. .

\begin{tabular}{|c|c|c|c|c|c|c|c|}
\hline 18 & $\mathrm{Ct}$ & $\begin{array}{l}18 \\
17\end{array}$ & $\mathrm{Ct}$. & & $\mathrm{Ct}$ & & $p$ \\
\hline 6 & ) & 4 & $n$ & & $\Rightarrow$ & & \\
\hline 5 & ) & 6 & $\eta$ & 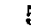 & $n$ & & \\
\hline 46 & D) & 47 & $\eta$ & 45 & $\nu$ & & \\
\hline 16 & D) & 16 & ס & 10 & " & & \\
\hline 9 & n & 8 & $\eta$ & 8 & $n$ & & \\
\hline
\end{tabular}

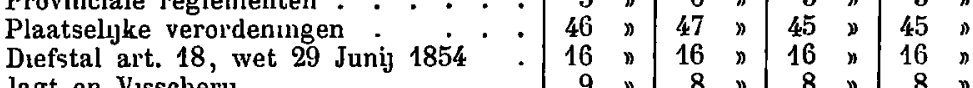

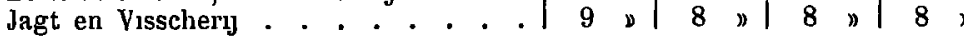

\begin{tabular}{cccc} 
Strafzaken & \multicolumn{3}{c}{ Gemiddeld. } \\
& $1855 / 59$ & $1 \cdot 4130$ \\
Beklangden & $1860 / 64$ & $1 \cdot 4702$ \\
(Regtbinh( 1 u) & $1855 / 59$ & 1 & 244 \\
& $1860 / 64$ & $1: 236$
\end{tabular}


TABeL G.

\section{VERHUIZINGEN.}

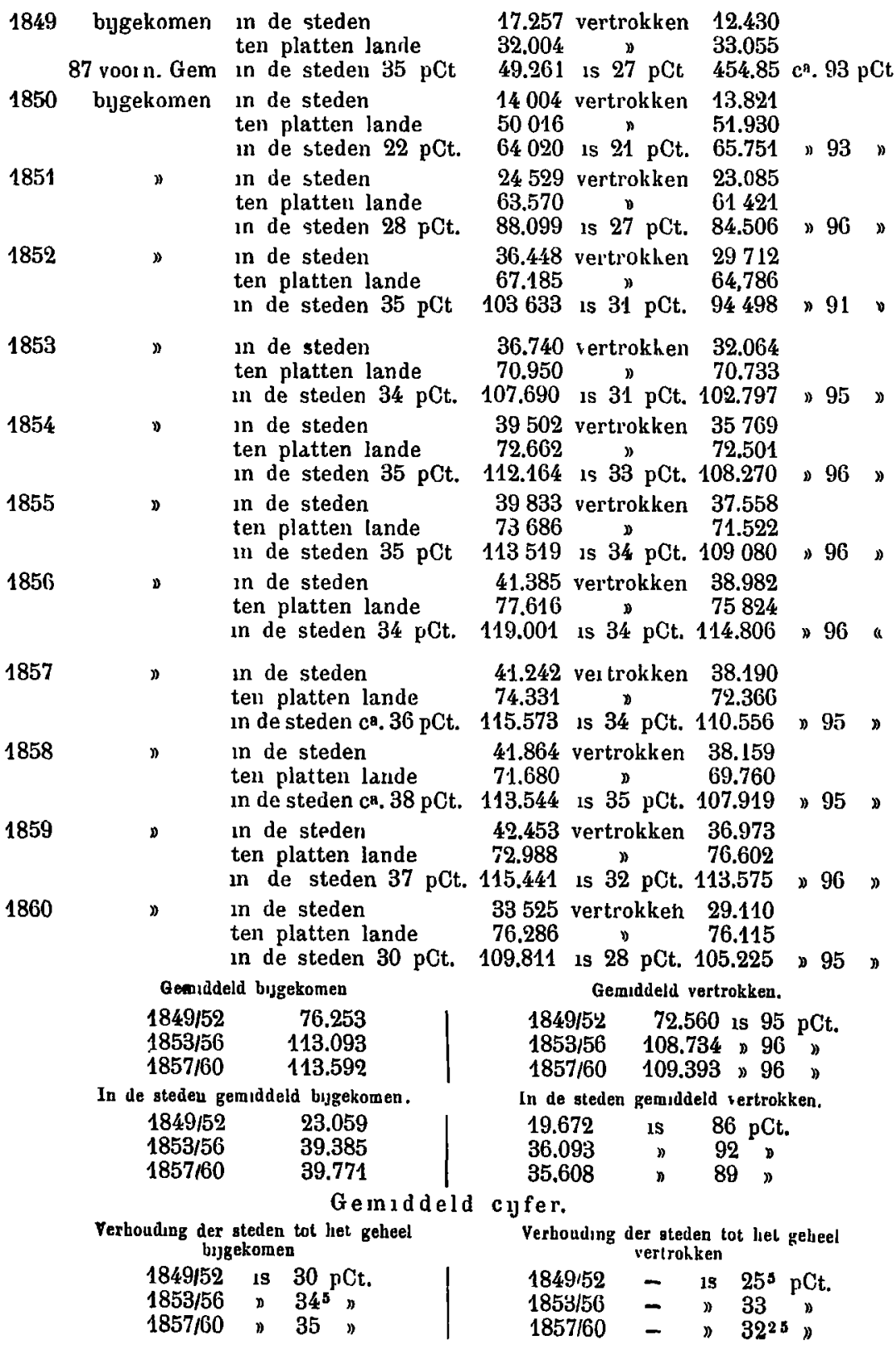

